Journal of

Business and Strategic

Management

(JBSM)

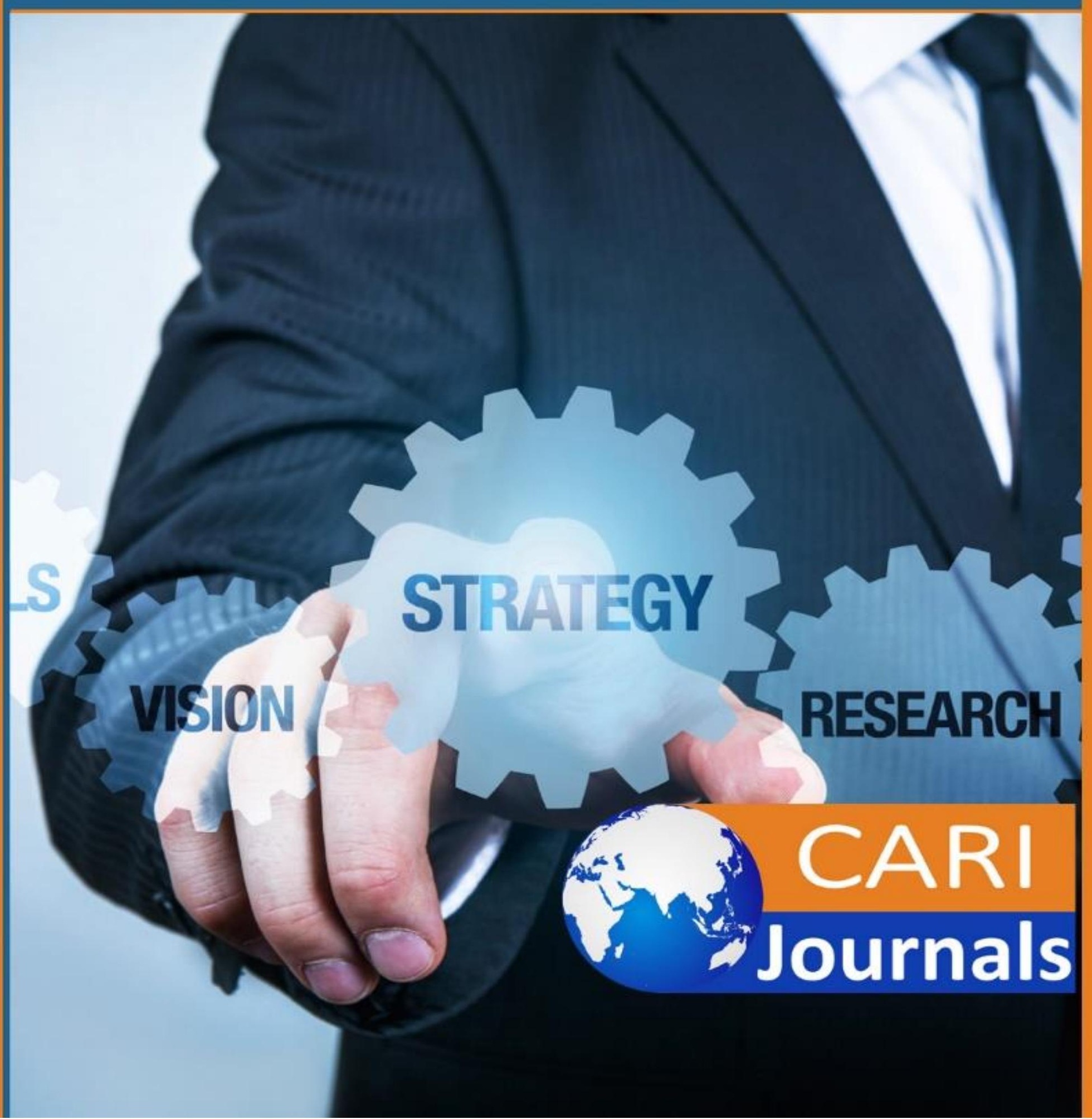




\title{
Influence of Strategic Resource Allocation by Laikipia County Government on Service Delivery in Level 3 and 4 Public Health Facilities
}

\author{
${ }^{1 *}$ Evaline Nasieku Lesiyampe \\ *Corresponding Author's E-mail: evalynnasiekulesiyampe@ gmail.com \\ ${ }^{2}$ Vivian Cherono, $\mathrm{PhD}$ \\ ${ }^{3}$ Rosemary Muriiki \\ ${ }^{[1,2,3]}$ Kenya Methodist University
}

\begin{abstract}
Purpose: The purpose of the study was to examine the influence strategic resource allocation by Laikipia county government on service delivery in level 3 and 4 public health facilities.

Methodology: The target population comprised of a sample of 74 medical practitioners. The respondents were doctors, nurses, pharmacists, lab technicians, radiologists, teaching staff and administration staff. Descriptive survey design was adopted for the study. Primary data was collected through questionnaires. Simple random sampling technique was used in guiding the selection of the study sample. A pilot study was conducted in 10 percent of the study sample from Naivasha County. Before administering the instruments, they were subjected to validity checks and reliability tests. Data analysis was done using tools in the SPSS version 25. Analysis involved computation of descriptive statistics such as frequencies, percentages, means and inferential statistics such as Pearson Correlation and regression analysis. The data was then presented in tables and narrations.
\end{abstract}

Results: The study established that the connection between the strategic resource allocation services and service delivery was statistically positive and significant hence the model can be used to predict the results of level 3 and 4 public health facilities in Laikipia county. It had an R value of .851 and an $\mathrm{R}$ square value of .723. Explained further it indicated that strategic resource allocation model forecasted $72.3 \%$ change on service delivery. Strategic resource allocation had a $\beta=.324, \mathrm{P}=449$.

Unique contribution to theory, policy and practice: Though there were resources enough to obtain various medical supplies, there was a gap in ensuring that departments got all the requirements they were in need of. The study discovered that mis-balance between departments getting required resources in which they are dispensed to. The study recommended that there should be clear resource tracking within the departments. There should be easy and less bureaucratic replenishing of the resources since these departments have generated them. There should be policies put into place to factor in quick, reliable and quality replenishing within various departments of hospitals.

Keywords: Strategic resource allocation, service delivery, Laikipia County, public health facilities 
Journal of Business and Strategic Management

ISSSN 2520-0402 (Online)

Vol.6, Issue No. 1, pp 62-77, 2021

$\underline{\text { www.carijournals.org }}$

\subsection{INTRODUCTION}

The consistency of medical services rendered by rival public hospitals is the patients' primary factor when deciding the selection for treatment of a specific hospital. The 58th World Health Organization Assembly (WHO) of 2005 encouraged member countries to seek to provide universally accessible health care to all members of the population on the basis of equality and solidarity values. Universal health coverage (UHC) has subsequently picked up fame as a worldwide wellbeing objective. Part States of the United Nations (UN) supported UHC in 2012 goals and in 2015 embraced it as the Sustainable Development Target (SDG). Universal health coverage entails access to safe, reliable, comprehensive essential healthcare services, including affordable vital drugs and vaccines for all without falling into poverty, is universal health coverage (Boudreau, 2017).

In advanced economies such as America, the government has been struggling a lot on cost expenditure vote healthcare, insufficient preventive services innovations (Covid 19) epidemic; insufficient insurance covers for all classes of citizens (Papanicolas et al., 2019; Boudreau, 2017; Osborn et al., 2016). In Europe, universal health system has had issues such as high fragmentation of health system; high costs of premiums paid even when there are no claims made for a lengthy period; disparity between unfulfilled medical care needs by the income group, inefficiencies in timely delivery of health services, low allocation of health care funds in the European nations' budget projections (Cherny et al., 2016). In Asia there have been drawbacks such as legal assurance unclear clauses on compensations to subscribers, risk pulling short comings like excessive claims in one move, lack of sufficient finances allocation in the national budget in a country such as Nepal (Deloitte, 2019; Ranabhat et al., 2019). A country like Indonesia health schemes have been causing the national budget to experience budget deficits causing reduced margins at the hospitals catty due to unavailability of funds (World Health Organization, 2019b).

Kenya, alongside other member states of the United Nations (UN), is working for universal health coverage around the world by the year 2030 (Otieno, 2016). Universal Health Coverage (UHC) is described, according to the World Health Organization, as the right of individuals to access the health services they need without suffering financial hardship (Kenya National Commission on Human Rights [KNCHR], 2018). To further break it down, this guarantees that all people and networks can utilize the instructive, preventive, therapeutic, remedial and palliative wellbeing administrations they need, of sensible quality to be effective, while guaranteeing that the utilization of such administrations doesn't expose them to money related challenges Kenya Research Medical Institute (Kenya Research Medical Institute [KEMRI], 2019). Given that the Kenya Vision 2030 plans to transform Kenya into a recently industrializing, center salary nation giving all its people with a high quality of life by 2030, universal health care is crucial. Kenya's government has introduced the Universal Health Coverage (UHC) pilot program known as Afya Care - Wema Wa Mkenya, which have empowered Kenyans to access affordable healthcare without financial difficulties. The County Governments in Kenya have placed at the center of the implementation of the UHC programs (KCNHR, 2018). 
Journal of Business and Strategic Management

ISSSN 2520-0402 (Online)

Vol.6, Issue No. 1, pp 62-77, 2021

www.carijournals.org

\subsection{Statement of the problem}

Hospitals are expected to provide affordable healthcare services, which are of good quality. However, across the country, there are reports of poor healthcare and inability of patients to access affordable healthcare services. There are incidences of lack of resources in most of the facilities (Lobelo et al., 2014). For instance, the shortage of drugs supplied by medical facilities in the country for nearly a year as a result of the debt of Sh285 million which KEMSA had withdrawn from the debt supply of drugs which had accrued since 2014 (Mueni, 2019).

Inadequate expertise and skills have also been attributed to the provision of poor-quality care, exacerbated by wider program deficiencies and low staff numbers. In the year 2015, an acute drug shortage hit various public hospitals and other health facilities in Laikipia county forcing patients to opt for private hospitals. This was after the county government failed to supply the drugs to the institutions for the last three months. There is a fair mix of public, faith-based and private health facilities in Laikipia County. However, there are significant challenges to access drawn from physical, financial, cultural and service barriers. The superiority of healthcare amenities provided by the medical centers remains unimpressive (Kenya National Commission on Human Rights [KNCHR], 2018).

While much has been written about problems related to resource allocation in medicine, there has been less debate about how resource allocation influences public health. Previous studies such as Mutua et al. (2011), the provision of public health services in hospitals lacks priority that should be enjoyed in relation to the dedication of workers, the availability of necessary materials and equipment, technology and communication networks that translate into other delivery of health services. These situations bring to perspective questions as to how the strategic healthcare services adopted by Laikipia County influence service delivery in public hospitals, and this is the motive of this study.

Other previous studies by Mutui (2006), Mayoli (2008) and Mwenda (2012) have investigated the influence of government initiatives to provision of health services, community involvement and provision of public health services and the future prospects on the sustainability of community health strategy respectively in Kenya. However, in there have been no study that had been established to examine the influence of strategic healthcare services adopted by Laikipia County on service delivery in public hospitals. This created a gap that this study sought to know what influence existed.

\subsection{Purpose of the study}

The purpose of the study was to examine the influence strategic resource allocation by Laikipia county government on service delivery in level 3 and 4 public health facilities.

\subsection{Hypothesis}

Ho: Strategic resource allocation by Laikipia County does not have a statistically significant influence on service delivery in level 3 and 4 public health facilities. 
Journal of Business and Strategic Management

ISSSN 2520-0402 (Online)

Vol.6, Issue No. 1, pp 62-77, 2021

www.carijournals.org

\subsection{LITERATURE REVIEW}

\subsection{Theoretical Review}

Resource based theory was postulated by Barney (1991). It guided the strategic resource allocation and strategic procurement variables of the study. At the organizational level, the theory is used to examine the relationships between materials, competitiveness and productivity, including the analysis of successful replication, the suitability of returns to innovation, the role of incomplete knowledge in causing differences in profits between competing firms and the means by which the resource accumulating mechanism can sustain competitiveness. These contributions together contribute to what has been dubbed "the company's resource-based view." However, the consequences for strategic management of this "resource-based theory" remain vague for two reasons. First there is a lack of a common integrative structure for the different contributions. Second, there was very little attempt to establish the practical consequences of this theory. This theory suggests a resource-based strategy formulation approach that incorporates a range of key principles drawn from the Strategic Planning literature. The process includes a five-stage strategy creation process; the analysis of the company's resource base; the evaluation of the company's capacities; the analysis of the company's revenue-earning potential; the choice of a strategy and the development and enhancement of the company's resource and performance reservoir (Rumelt, 1984).

The theory was pertinent to this investigation in that county governments need to get involved in securing and procurement of new and additional resources for the enhancement of service delivery in hospitals. The theory supported the fact that governments need to employ these resourceoriented strategies so as to make better use of, and maximize, existing resources. Strategies such as strategic resource allocation and human resource development are arguably ideal for this aim according to this theory.

\subsection{Empirical Review}

According Milano and McTaggart (2018), strategic resource allocation involves ensuring allocation from several different perspectives. This can be across functional areas such as accounting, R\&D, human resources, logistics, marketing. For example, a second way to determine resources is by form, physical resources, financial resources, human resources and institutional resources. The resources may also be measured and distributed according to their tangibility. You may track and quantify measurable resources (such as a factory, or the number of employees). Less measurable resources (such as the corporate name) are also significant, although their characteristics and importance are more difficult to determine.

Pooyan et al. (2018) studied the effect of resource allocation decisions on efficiency and equity in health in 11 countries. These countries included USA, North Africa, Greece, China, Australia, Taiwan, and South Africa. The study found that the main methods for resource allocation included: linear programming, Markov model, cost-effectiveness analysis, per capita resource allocation, modelling the resource allocation. However, the study did look at the influence of these asset distribution methods on facility conveyance. 
Journal of Business and Strategic Management

ISSSN 2520-0402 (Online)

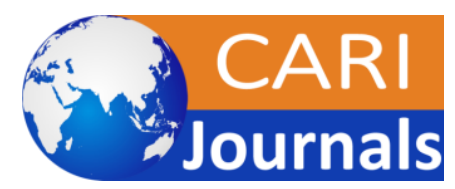

Vol.6, Issue No. 1, pp 62-77, 2021

www.carijournals.org

In a study in Turkey by Gok and Altındağ (2014) appropriate allocation of health resources and efficient use of these facilities is considered to be critical, and the assessment and proper correction of the health system seems inevitable, and this correction is possible through an examination of policies, increased efficiency, limitation of unnecessary costs, and responding to the needs of society.

In a study by Otieno (2016) in Baringo County, there was no criteria or formula for financial resource allocation; there was skewed distribution of the human resources with some sub counties being "favoured" while others were "disadvantaged" and finally there was evident of political interference with the distribution of the health resources. There is disparity of both financial and human resources allocation/distribution among the sub-counties of Baringo County. It was shown that East Pokot sub-county had the highest population, the largest land area, the highest average distance to a facility but had the lowest per capita expenditure and the least health human resource per 100,000 population. The study also found that due to strong political influence on resource allocation, it would be difficult to develop equity in distribution of resources. However, the study did not examine the influence of resource allocation on service delivery.

Mwangi (2015) inspected the connection between key arrangement execution and administration conveyance at National Hospital Insurance Fund (NHIF). The investigation likewise presumes that asset designation has significant ramifications on the capacity and pace of key arrangement execution and thus administration conveyance. The examination presumes that there are a few difficulties looked in the usage of key arrangement at NHIF, for example, absence of correspondence between the methodology formulators and the representatives. The examination found that asset assignment has significant ramifications on the capacity and pace of vital arrangement execution and consequently administration conveyance. The investigation along these lines suggested that the division liable for key arrangement execution ought to be furnished with satisfactory assets since it assumes a basic job in vital arrangement usage.

\subsection{Research Gap}

Even though the literature review demonstrated the significance of strategic healthcare services employed by various governments, the studies failed to relate this aspect to the provision of quality health services. For instance, a study by Milano and McTaggart (2018) on USA, North Africa, Greece, China, Australia, Taiwan, and South Africa did look at the effect of these resource allocation methods on service delivery. A study by Otieno (2016) showed that the use of human resources was inadequate due to capital ineptitude, such as hospital equipment but does not show how the strategies employed help enhance the provision of quality healthcare services.

\subsection{RESEARCH METHODOLOGY}

The target population comprised 84 health facilities connected to an electronic medical records platform (County Government of Laikipia, 2019). This helped ensure that the target population was drawn from a relevant universe. There were around 25 doctors, 336 nursing staff, 84 pharmacists, 125 lab technicians, 25 radiologists, 20 teaching staff and 84 administration staff. The total was 653 staff (County Government of Laikipia, 2019). The analysis employed technique of stratified random sampling. Stratified random sampling is an examining procedure including the parting of a populace into littler subgroups known as layers. The layers are shaped in delineated 
Journal of Business and Strategic Management

ISSSN 2520-0402 (Online)

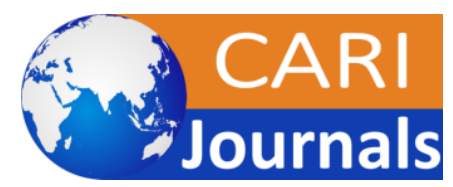

Vol.6, Issue No. 1, pp 62-77, 2021

www.carijournals.org

irregular examining or separation dependent on the basic qualities or attributes of the members (Mugenda \& Mugenda, 2003). The technique was used to select participants from various cadres within the hospitals. In this case, the strata were doctors, nurses, pharmacists, lab technicians, and radiologists forming the management staff, teaching staff and administration staff formed the nonmanagement staff. This formed a sample of 74 combined medical practitioners who were a sample of 3 doctors, 36 nurses, 9 pharmacists, 9 lab technicians and 2 radiologists forming a total of 59 management staff. In addition, 2 teaching staff and 13 administration staff formed a total of 15 non- management staffs. However, the combined total was 74 respondents. Descriptive survey design was adopted for the study. Primary data was collected through questionnaires. Simple random sampling technique was used in guiding the selection of the study sample. A pilot study was conducted in 10 percent of the study sample from Naivasha County. Before administering the instruments, they were subjected to validity checks and reliability tests. Data analysis was done using tools in the SPSS version 25. Analysis involved computation of descriptive statistics such as frequencies, percentages, means and inferential statistics such as Pearson Correlation and regression analysis. The data was then presented in tables and narrations.

\subsection{FINDINGS AND PESENTATION}

\subsection{Reliability statistics}

To ensure that the study performed their required tasks on underpinning the objectives, the study did a pilot study on both the questionnaires and interview guides. The pilot study was conducted in Naivasha sub-county hospital. There were 5 hospital staff through which the questionnaires were tested on. The five staff were selected through random sampling technique. Table 1 gave the results derived thereof.

Table 1: Reliability Statistics

$\begin{array}{lll}\text { Instrument } & \text { Cronbach's Alpha } \quad \mathrm{N} \text { of Items }\end{array}$

Questionnaire

.89

5

Results from Table 1 indicated that the questionnaires had a Cronbach alpha coefficient of 0.89. As indicated by Kothari and Garg (2014), A relationship coefficient of more than 0.7 was viewed as adequately high to order the instruments as precise. Therefore, this research instruments produced an average coefficient of 0.89 hence they were reliable enough to be utilized for the investigation.

\subsection{Response rate}

The study had an objective of getting data from 74 public hospitals personnel. The 74 personnel were 3 doctors, 36 nurses, 9 pharmacists, 9 lab technicians and 2 radiologists forming a total of 59 management staff. 2 teaching staff and 13 administration staff formed a total of 15 nonmanagement staffs. However, the combined total was 74 respondents. On the one hand, when the researcher issued the 74 public hospital personnel with the questionnaires, the returned ones were 
Journal of Business and Strategic Management

ISSSN 2520-0402 (Online)

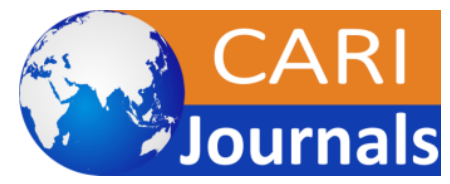

Vol.6, Issue No. 1, pp 62-77, 2021

www.carijournals.org

64 implying that the response rate was $86 \%$. The unanswered questionnaires were 10 representing $14 \%$.

\subsection{Background profiles of the respondents}

At the commencement of the research instruments, the researcher was keen on introducing the questions by first knowing few demographic data of the respondents. Table 2 gives the demographic data of the respondents answering the questionnaires and the respondents being interviewed. Results from Table 4.3 indicated that there were mor females than males. The number of female personnel were $36(56 \%)$ while the number was male personnel were $28(44 \%)$. This high number of female staff came mostly from the nurses and support staff. A similar finding was established by ministry of health report (2018) confirmed that it found out that nurses forming majority of hospital staff, female nurses were more as compared to male nurses.

Therefore, since in our case there were more nurses and support staff, we established that there were more female than male staff. Table 4.3 also showed that most hospital staff ages ranged between 34-48 years who were 24(38\%), followed by 28-37 years who were 15(23\%); followed by 18-27 years who were 13(20\%); and those above 48 years came last since they were just 12(19\%). Akacho (2014) derived results that were relatable to the study after establishing that most medical staff in Uasin Gishu district hospital in Eldoret were middle aged between their late 20's and early 50's.

Table 2: Demographic Profile of the Respondents

\begin{tabular}{lccc}
\hline Gender Category & Frequency & Percent & Cumulative Percent \\
\hline Male & 28 & 44 & 44 \\
Female & 36 & 56 & 100 \\
Total & $\mathbf{6 4}$ & $\mathbf{1 0 0}$ & \\
\hline Age Category & Frequency & Percent & Cumulative Percent \\
\hline 18-27 years & 13 & 20 & 20 \\
$28-37$ years & 15 & 23 & 43 \\
$38-47$ years & 24 & 38 & 81 \\
48 and above & 12 & 19 & 100 \\
Total & $\mathbf{6 4}$ & $\mathbf{1 0 0}$ & \\
\hline Job title Category & Frequency & Percent & Cumulative Percent
\end{tabular}


Journal of Business and Strategic Management

ISSSN 2520-0402 (Online)

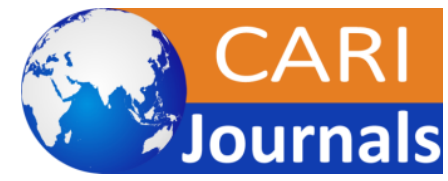

Vol.6, Issue No. 1, pp 62-77, 2021

www.carijournals.org

\begin{tabular}{|c|c|c|c|}
\hline Senior manager & 2 & 3 & 3 \\
\hline Doctor & 2 & 3 & 6 \\
\hline Nurse & 19 & 30 & 36 \\
\hline Pharmacist & 5 & 7 & 43 \\
\hline Lab technician & 7 & 11 & 54 \\
\hline Radiologists & 1 & 2 & 56 \\
\hline Teaching staff & 2 & 3 & 59 \\
\hline Admin staff & 8 & 13 & 72 \\
\hline Support staff & 18 & 28 & 100 \\
\hline Total & 64 & 100 & \\
\hline Period Category & Frequency & Percent & Cumulative Percent \\
\hline $0-3$ years & 16 & 25 & 25 \\
\hline 4-6 years & 22 & 34 & 59 \\
\hline $7-9$ years & 21 & 33 & 92 \\
\hline 10 and above & 5 & 8 & 100 \\
\hline Total & 64 & 100 & \\
\hline
\end{tabular}

Table 2 indicated that most of the hospital staff were nurses and support staff who we 19(30\%) and $18(28 \%)$ respectively. True to these results Kenya Conference of Catholic Bishops (KCCB) report in 2014 agreed that majority of their staffs were nurses who were 2750(29.5\%) and support staff who were 673(16\%) of their total 9323 hospital staffs. According to Table 2 most of the employees had stayed in their current hospital for a period between 4-6 years who were 22(34\%); they were closely followed by 7-9 years who were $21(33 \%)$. The least duration was discovered to be ten years and above who were only 5(8\%). Badr et al. (2013) while considering health sector human resources in Sudan indicated that most staff had stayed in the hospital between 3-7 years. Actually, in this study 4-6 years also fell in that range.

\subsection{Descriptive statistics of strategic resource allocation}

The key objective of the study was to establish influence of strategic resource allocation by Laikipia County Government on service delivery in level 3 and 4 public health facilities. To 
Journal of Business and Strategic Management

ISSSN 2520-0402 (Online)

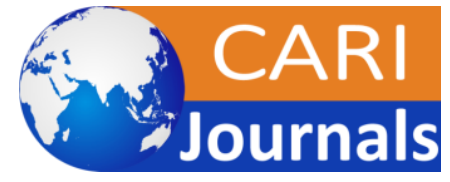

Vol.6, Issue No. 1, pp 62-77, 2021

www.carijournals.org

achieve this objective, the researcher developed a questionnaire that had statements and also interview questions. In the questionnaires, the respondents were either supposed to 1-Strongly disagree, 2-disagree, 3- Neither agree nor disagree, 4- Agree and 5- Strongly agree. Table 3 gave the results derived.

Table 3: Descriptive Statistics on Strategic Resource Allocation

\begin{tabular}{lllllllll}
\hline $\begin{array}{l}\text { Statements } \\
\mathrm{N}=64\end{array}$ & 1 & 2 & 3 & 4 & 5 & Mean Std Dev \\
\hline
\end{tabular}

Our facility has

adequate

resources for

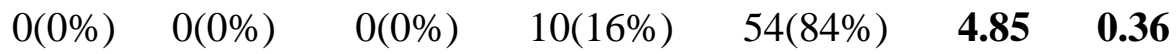

research and

development

There are

adequate

finances for

departmental

operations at the

$\begin{array}{lllll}0(0 \%) & 4(6.0 \%) & 0(0 \%) & 8(13 \%) & 52(81 \%)\end{array}$

$4.68 \quad 0.78$

facility

Our department

has enough

resources to

obtain requisite

$1(1 \%) \quad 0(0 \%) \quad 0(0 \%) \quad 5(8 \%)$

$58(91 \%)$

$4.87 \quad 0.51$

medical supplies

Our department

has all requisite

operational

equipment.

$3(5 \%) \quad 13(20 \%) \quad 0(0 \%) \quad 27(42 \%) \quad 21(33 \%)$

4.50

0.78 
Journal of Business and Strategic Management

ISSSN 2520-0402 (Online)

Vol.6, Issue No. 1, pp 62-77, 2021

www.carijournals.org

Our department

has adequate

$\begin{array}{llllllll}\text { manpower for it } & 0(0 \%) & 3(4.7 \%) & 1(1.3 \%) & 16(25.0 \%) & 44(69.0 \%) & \mathbf{4 . 5 8} & \mathbf{0 . 7 5}\end{array}$

to function well

Average Mean

$4.69 \quad 0.64$

The results from Table 3 indicated that strategic resource allocation had an average mean of 4.69 and a standard deviation of 0.64 . The most agreed statement by the hospital personnel were departments had enough resources to obtain requisite medical supplies. It had a mean of 4.87 and a standard deviation of .510. The most disagreed statement by hospital personnel were that departments had all requisite operational equipment. It had a mean of 4.50 and a standard deviation of .784. From these two responses one thing was clear. Though there were resources enough to obtain various medical supplies, there was a gap in ensuring that departments got all the requirements they were in need of. The researcher discovered that mis-balance between departments getting required resources in which they are dispensed to was not just a Kenyan problem. In Nigeria, Etiaba et al. (2018) indicated that there was still resource allocation problem to social health insurance scheme, whereby the scheme has been suffering from shortages of funding despite funds being present.

\subsection{Service Delivery in Level 3 and 4 Public Health Facilities in Laikipia County}

The study also assessed service delivery by Laikipia County Government in level 3 and 4 public health facilities. Service delivery had indicators such as quality healthcare service and affordable healthcare service. The researcher developed a questionnaire that had statements to hospital staffs and also interview questions to senior hospital management. In the questionnaires, the respondents were either supposed to indicated whether service delivery was 1-very poor, 2-poor, 3- fair, 4good or 5- very good. Table 4 indicated what was found out.

Table 4: Descriptive Statistics on Service Delivery

\begin{tabular}{lllllllll}
\hline $\begin{array}{l}\text { Statements } \\
\mathrm{N}=64\end{array}$ & 1 & 2 & 3 & 4 & 5 & Mean & Std Dev \\
\hline
\end{tabular}

Quality of

service rendered

$1(1.2 \%) \quad 1(1.2 \%) \quad 0(0 \%) \quad 6(9.5 \%) \quad 56(88.1 \%)$

$4.84 \quad .60$

Timeliness in service delivery

$$
0(0 \%) \quad 8(11.9 \%) \quad 0(0 \%) \quad 19(31.0 \%) \quad 37(57.1 \%)
$$

4.33 
Journal of Business and Strategic Management

ISSSN 2520-0402 (Online)

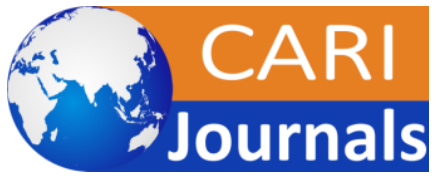

Vol.6, Issue No. 1, pp 62-77, 2021

www.carijournals.org

Supplies /

Reagents/Drug

availability

$5(7.1 \%) \quad 19(29.8 \%) \quad 0(0 \%)$

$23(35.7 \%) \quad 17(27.4 \%) \quad \mathbf{3 . 4 6}$

.36

Equipment

availability

$2(2.4 \%) \quad 8(13.1 \%)$

$16(25.0 \%)$

$6(9.5 \%)$

$32(50.0 \%)$

3.92

.22

Caseload per
health provider

$5(7.1 \%) \quad 27(42.9 \%) \quad 0(0 \%)$

$32(50.0 \%) \quad 0(0 \%)$

2.93

.11

Diagnostic

$2(2.4 \%) \quad 7(11.9 \%) \quad 2(2.4 \%)$

$19(29.8 \%) \quad 34(53.6 \%)$

$4.20 \quad .11$

accuracy

Adherence to set

operational

$5(8.3 \%) \quad 16(25.0 \%) \quad 1(1.2 \%)$

$24(38.1 \%) \quad 18(27.4 \%)$

3.51

.35

guidelines

\section{Average Mean}

3.88

0.10

Statistics from Table 4 showed that service delivery in Level 3 and 4 public health facilities had an average mean of 3.88 and a standard deviation of 1.10. It was true that the quality of service rendered significantly very good on a mean of 4.84 and a standard deviation of 0.604 . Despite the quality improving it was noticed that caseload per health provider had a low mean of 2.93 and standard deviation of 1.106. This meant that there was overworking aspect in Level 3 and 4 public hospitals in Laikipia county. A report by ministry of health (2017) hinted on reducing work load per medical staff in Kenya as a strategy of transforming health to achieve universal health coverage.

\subsection{Model Summary}

Strategic resource allocation model explained what proportion of this variable caused change on service delivery. It had an $\mathrm{R}$ value of .851 and an $\mathrm{R}$ square value of .723. Explained further it indicated that strategic resource allocation model forecasted $72.3 \%$ change on service delivery. Table 5 showed the results gotten. 
Journal of Business and Strategic Management

ISSSN 2520-0402 (Online)

Vol.6, Issue No. 1, pp 62-77, 2021

www.carijournals.org

Table 5: Strategic Resource Allocation Model Summary

\begin{tabular}{ccccc}
\hline Model & R & R Square & Adjusted R Square & $\begin{array}{c}\text { Std. Error of the } \\
\text { Estimate }\end{array}$ \\
\hline $.851^{\mathrm{a}}$ & .723 & .711 & 3.515 \\
\hline
\end{tabular}

a. Predictors: (Constant), Strategic resource allocation

\subsection{Analysis of Variance (ANOVA) on Strategic Resource Allocation}

Establishing the influence of strategic resource allocation by Laikipia County Government on service delivery in level 3 and 4 public health facilities, involved testing a hypothesis. The first hypothesis stated that strategic resource allocation by Laikipia County did not have a statistically significant influence on service delivery in level 3 and 4 public health facilities. Table 6 depicted the results derived.

Table 6: ANOVA for Linear Relationship Between Strategic Resource Allocation and Service Delivery

\begin{tabular}{lllllll}
\hline Model & & Sum of Squares & Df & Mean Square & F & Sig. \\
\hline & Regression & 851.474 & 1 & 851.474 & 1.9 & $.002 \mathrm{~b}$ \\
& Residual & $1,012.85$ & 82 & 12.352 & & \\
& Total & 1036.321 & 83 & & & \\
\hline
\end{tabular}

a. Dependent Variable: Service delivery

b. Predictors: (Constant), Strategic resource allocation

Results on Table 6 indicated that the significance p-values of the relationship were 0.02 which was less than 0.05 . Therefore, the researcher rejected the null hypothesis that strategic resource allocation by Laikipia County did not have a statistically significant influence on service delivery in level 3 and 4 public health facilities.

\subsection{Regression Coefficient}

In determining the coefficients of the variables, the study analyzed the multiple linear regression of the variables. The results as indicated in Table 7 showed that the strategic resource allocation had a $\beta=.324, \mathrm{P}=449$. 
Journal of Business and Strategic Management

ISSSN 2520-0402 (Online)

Vol.6, Issue No. 1, pp 62-77, 2021

www.carijournals.org

Table 7: Regression Coefficients

\begin{tabular}{lccccc}
\hline & $\begin{array}{c}\text { Unstandardized } \\
\text { Coefficients }\end{array}$ & $\begin{array}{c}\text { Standardized } \\
\text { Coefficients }\end{array}$ & t & Sig. \\
\hline & B & Std. Error & Beta & & \\
\hline & 19.58 & 4.821 & & 4.06 & 0.62 \\
& & & & 0.76 & \\
$\begin{array}{c}\text { Strategic resource } \\
\text { allocation }\end{array}$ & 0.324 & 0.425 & 0.169 & & 0.449 \\
\hline
\end{tabular}

a. Dependent Variable: Service delivery

The general model of the study was SDPH $=\mathrm{K}+\beta_{1}$ SRA $+\beta_{2}$ SHRD $+\beta_{3}$ SPPP $+\beta_{4}$ SITA $+\varepsilon$. Where: SDPH was service delivery in public hospitals; SRA was strategic resource allocation; When the coefficients were put into the model as from Table 7, the model was: Service delivery $=19.580 \mathrm{~K}+0.324 \mathrm{SRA}$. That was to say by adding a unit of SRA, service delivery increased by $19.580+0.324$.

\subsection{SUMMARY, CONCLUSION AND RECOMMENDATION}

\subsection{Summary of the findings}

The key objective of the study was to establish influence of strategic resource allocation by Laikipia County Government on service delivery in level 3 and 4 public health facilities. The results indicated that strategic resource allocation had an average mean of 4.69 and a standard deviation of 0.64 . It was discovered that though there were resources enough to obtain various medical supplies, there was a gap in ensuring that departments got all the requirements they were in need of. The researcher discovered that mis-balance between departments getting required resources in which they are dispensed to. Strategic resource allocation model explained what proportion of this variable caused change on service delivery. It had an $\mathrm{R}$ value of .851 and an $\mathrm{R}$ square value of .723. Explained further it indicated that strategic resource allocation model forecasted $72.3 \%$ change on service delivery. Strategic resource allocation had a $\beta=.324, P=449$.

\subsection{Conclusion}

The study rejected the null hypothesis that strategic resource allocation by Laikipia County did not have a statistically significant influence on service delivery in level 3 and 4 public health facilities. This was because significance p-value of the relationship was 0.02 which was less than 0.05 . Therefore, the researcher concluded that there was a strong positive statistical significance influence between strategic resource allocation and service delivery.

\subsection{Recommendations and Contributions of the Study}

Though there were resources enough to obtain various medical supplies, there was a gap in ensuring that departments got all the requirements they were in need of. The study discovered that 
Journal of Business and Strategic Management

ISSSN 2520-0402 (Online)

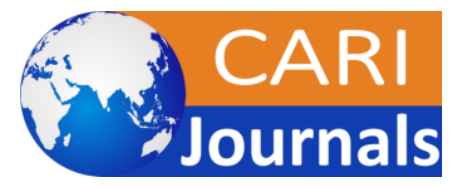

Vol.6, Issue No. 1, pp 62-77, 2021

WwW.carijournals.org

mis-balance between departments getting required resources in which they are dispensed to. The study recommended that there should be clear resource tracking within the departments. There should be easy and less bureaucratic replenishing of the resources since these departments have generated them. There should be policies put into place to factor in quick, reliable and quality replenishing within various departments of hospitals.

\section{REFERENCES}

Akacho, E.N. (2014). Factors influencing provision of Health care service delivery in Kenya: A case of Uasin Gishu District Hospital in Eldoret [Master's Thesis, University of Nairobi]. Nairobi, Kenya. https://pdfs.semanticscholar.org/d3db/11bb9bffd9708b50deaf23356e03b6556990.pdf?_g $\mathrm{a}=2.195126508 .1143259703 .1591795611-199641240.1584249034$

Badr, E., Nazar, M.A., Afzal, M.M., Bile, K. M. (2013). Strengthening human resources for health through information, coordination and accountability mechanisms: The case of the Sudan. Bull World Health Organization, 91(19), 868-873 https://doi.org/10.2471/BLT.13.118950

Barney, J. B. (1991). Firm resources and sustained competitive advantage. Journal of Management, 17(6), 99-120. https://josephmahoney.web.illinois.edu/BA545_Fall\%202019/Barney\%20(1991).pdf

County Government of Laikipia (2019). Annual development plan 2020/2021. http://laikipiaassembly.go.ke/assets/file/8de4825f-annual-development-plan-20202021.pdf

Etiaba, E., Onwujekwe, O., Honda, A., Ibe, O., Uzochukwu , B., Hanson, K. (2018). Strategic purchasing for universal health coverage: Examining the purchaser-provider relationship within a social health insurance scheme in Nigeria. BMJ Global Health, 3(5), 91-97. https://doi.org/10.1136/bmjgh-2018-000917

Gok, M.S., \&Altindag, E. (2014). Analysis of the cost and efficiency relationship: experience in the Turkish pay for performance system. The European Journal of Health Economics, 16(5), 1-10. https://doi.org/10.1007/s10198-014-0584-6

Kenya Conference of Catholic Bishops (2014). Medical staff report. https://www.health.go.ke/wpcontent/uploads/2016/04/Kenya-HRH-Strategy-2014-2018.pdf

Kenya National Commission on Human Rights (2018). The right to health. A case study of Kisumu County.

http://www.knchr.org/Portals/0/OccasionalReports/The\%20Right\%20to\%20Health\%20in $\% 20$ Kisumu\%20County.pdf?ver=2018-01-18-142546-863

Kothari, C.R., \& Garg, G. (2014), Research methodology, (3 ${ }^{\text {rd }}$ ed.). New. Age International Publishers, New Delhi.

Lobelo, F., Stoutenberg, M., Hutber., A. (2014). The exercise is medicine Global Health Initiative: A 2014 update. British Journal of Sports Medicine, 48(22), 1627-1633. https://pubmed.ncbi.nlm.nih.gov/24759911/ 
Journal of Business and Strategic Management

ISSSN 2520-0402 (Online)

Vol.6, Issue No. 1, pp 62-77, 2021

$\underline{\text { www.carijournals.org }}$

Mayoli, A.M. (2012). An evaluation of effectiveness of community health systems in Kitui district [Master's Thesis, Mt. Kenya University]. Nairobi, Kenya. https://erepository.mku.ac.ke/handle/123456789/54

Milano, G., \& McTarggart, J. (2018). Overcoming 3 roadblocks to strategic resource allocation. https://www.financialexecutives.org/FEI-Daily/February-2018/Strategic-ResourceAllocation.aspx

Ministry of Health (2018). Health sector: Human resource strategy 2014-2018. https://www.health.go.ke/wp-content/uploads/2016/04/Kenya-HRH-Strategy-20142018.pdf

Ministry of Health (2017). Transforming health: Accelerating attainment of universal health coverage: The Kenya Health Sector Strategic and Investment Plan - KHSSP. http://ecavi.com/wp-content/uploads/2014/11/kenya-health-sector-strategic-investiment-plan2013-to-2017.pdf

Mugenda, O. M. \& Mugenda, A. G. (2003). Research methods: Quantitative and qualitative approaches. African Centre for Technology Studies.

Mutua, M. K., Kimani-Murage, E., \& Ettarh, R. R. (2011). Childhood vaccination informal urban settlements in Nairobi, Kenya: Who gets vaccinated. BMC PublicHealth,11(1), 6-16. https://bmcpublichealth.biomedcentral.com/articles/10.1186/1471-2458-11-6

Mutui, A.S. (2006). The relationship between culturally appropriate public health and hygiene practices use in rural Sichnan [PhD Thesis, Harvard University]. America. https://pdfs.semanticscholar.org/fa5a/11eb0c727050010ca2d0fa916bcb4330ddb0.pdf

Mwenda, A.M. (2012). Quality health service provision and of hygiene practices among the slum dwellers use: The case of a Kenyan slum. [Master's Thesis, Kenyatta University]. Nairobi, Kenya. https://www.ncbi.nlm.nih.gov/pmc/articles/PMC2134844/

Otieno, M. (2016). Resource allocation to health sector at the county level and implications for equity. A case study of Baringo county [Master's Thesis, University of Nairobi]. Nairobi, Kenya.

http://erepository.uonbi.ac.ke/bitstream/handle/11295/97910/Otieno_Resource\%20Alloca tion $\% 20$ to $\% 20$ Health\%20Sector\%20at\%20the\%20County\%20Level\%20and\%20Implicat ions\%20for\%20Equity,\%20a\%20Case\%20Study\%20of\%20Baringo\%20County..pdf?seq uence $=1 \&$ is Allowed $=\mathrm{y}$

Pooyan, E., Alipouri S.M., Mohtasham, F., \& Mostafavi, H. (2018). The effect of resource allocation decisions on efficiency and equity in the health sector: A systematic review. Caspian Journal of Health Research, 3(1), 28-34. https://doi.org/10.29252/cjhr.3.1.28.

Rumelt, R.P. (1984). Towards a strategic theory of the firm. Competitive Strategic Management, 26(2), 556-570. http://scholar.google.com/citations?user=p3NFT18AAAAJ\&hl=en

World Health Organization (2019). Governance for Strategic Purchasing: An analytical framework to guide a country assessment. https://apps.who.int/iris/bitstream/handle/10665/330247/9789240000025-eng.pdf 
Journal of Business and Strategic Management

ISSSN 2520-0402 (Online)

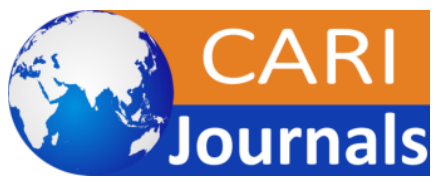

Vol.6, Issue No. 1, pp 62-77, 2021

www.carijournals.org

World Health Organization (2005). World health assembly concludes: Adopts key resolutions affecting global public health. https://www.who.int/mediacentre/news/releases/2005/pr_wha06/en/ 